Journal of Conflict \& Security Law (C) Oxford University Press 2018; All rights reserved. For permissions, please e-mail: journals.permissions@oup.com doi: $10.1093 /$ jcsl/kry023

\title{
How to Cope with Diversity While Preserving Unity in Customary International Law? Some Insights from International Humanitarian Law
}

\author{
Katharine Fortin*
}

\begin{abstract}
Drawing upon literature relating to armed groups and international law, this article provides insights on the question of whether customary international law can accommodate non-state actors at the level of duty-bearers and norm-makers. Demonstrating that customary international law can accommodate considerable diversity at the level of duty-bearers, it argues that customary international law will struggle to accommodate diversity at the level of its makers. In particular, it points out that the character of armed groups is so different from that of states, that it is unclear how their practice could be taken into account alongside those of states. Yet, the article demonstrates that there are also problems in a methodology relying upon only state practice and opinio juris, as evidence of customary norms binding on a diversity of actors. It shows that this is particularly the case for human rights law, where the identity of the norm-making entity 'as a state' is highly determinative of the nature of its practice and opinio juris.
\end{abstract}

\section{Introduction}

International law is frequently described with words such as 'unity' or 'unified' to denote the fact that it is a connected web of related rights and obligations. ${ }^{1}$ It is commonly said that international legal norms cannot be understood to exist in a vacuum but must be seen in relation to their place in the system. ${ }^{2}$ In recent decades, the unity of international law has been challenged, with fears expressed that it is becoming fragmented. ${ }^{3}$ Yet, it is notable that discussions of unity, fragmentation and diversification in international law at the level of norms

Assistant Professor, Utrecht University School of Law. E-mail: K.M.A.Fortin@uu.nl

1 M Craven, 'Unity, Diversity and the Fragmentation of International Law' in J Klabbers (ed), Finnish Yearbook of International Law (Martinus Nijhoff 2003) 3, 6-7.

2 Conclusions of the Work of the Study Group on the Fragmentation of International Law: Difficulties Arising from the Diversification and Expansion of International Law. Yearbook of the International Law Commission, 2006, vol II, pt II, A/CN.4/ SER.A/2006/Add.1 (pt 2), para 251, 177-78 (hereinafter Conclusions on Study Group on the Fragmentation of International Law).

3 C Greenwood, 'Diversity and Unity in International Law' in M Andenas and E Bjorge (eds), A Farewell to Fragmentation: Reassertion and Convergence in International Law (CUP 2015) 37. 
have focused mainly on treaty law. ${ }^{4}$ Most pertinently, it has been felt that a proliferation of increasingly specialised treaties has emerged, with little attention given by their drafters to the relationship between them. ${ }^{5}$ Secondly, the international treaty obligations that are in force for one state are different to the web of treaty obligations in force for another state, meaning that each state faces different challenges when it comes to safeguarding the normative coherence of the system. It also means that bilateral relationships between states on the same issues are often governed by different treaty regimes. One only has to think of the articulation of the lex posterior rule in Article 30 of the Vienna Convention, to see the different factors that need to be taken into account to identify which treaty rules will regulate a single issue between different states. ${ }^{6}$ The potential for problems caused by the lack of coherence between treaty regimes is well illustrated by the challenges faced by the European Court of Human Rights in reconciling states' obligations under the wording of Article 5 (right to liberty and security) of the European Convention, with their contemporaneous obligations under international humanitarian law. ${ }^{7}$

In recent years, the increased study of or perhaps the exposure to these forces seems to have caused the fear of fragmentation in treaty law to dissipate. These days, the prevailing view is that international law is not breaking up, but undergoing a necessary expansion and reshaping that can be managed in ways that preserve its coherence. For example, it has been remarked that despite diversity at the level of duty-bearers and primary norms, unity within the treaty law system can prevail through recourse to cross-cutting interpretational rules that keep the system of international law coherent and free of conflict. ${ }^{8}$ Perhaps, the most important of these rules is Article 31(3)(c) of the Vienna Convention that allows treaty terms to be interpreted in the light of their context, including 'any relevant rules of international law applicable in the relations between the parties'. This provision allows a state's treaty obligations to be interpreted in a manner that takes due account of their interrelationship with

4 ibid 40-46. It is noteworthy that three of the five topics adopted by the ILC for further study by its study group on fragmentation related explicitly to treaty law. Yearbook of the International Law Commission 2002, vol II, pt II, UN Doc A/57/10, para 512.

5 Report of the Study Group on the Fragmentation of International Law. Yearbook of the International Law Commission 2006, vol II, pt II, A/CN.4/SER.A/2006/Add.1 (pt 2), para 247, 177.

6 These factors include whether there is a clause in the treaty determining its relationship with a subsequent treaty, whether the provisions of the earlier treaty are compatible with the later treaty and whether both parties have signed the later treaty.

7 See Hassan v UK, App No 29750/09, Grand Chamber Judgment, 16 September 2014, paras 100-7. See also, Serdar Mohammed and Others (Respondents) v Ministry of Defence (Appellant) [2017] UKSC 2. For an exploration of how the ICJ has dealt with potential conflicts between IHL and IHRL, see L Hill-Cawthorne, 'Just Another Case of Treaty Interpretation? Reconciling Humanitarian and Human Rights Law in the ICJ' in Andenas and Bjorge (n 3).

8 Conclusions on Study Group on the Fragmentation of International Law (n 2) para 250; Greenwood (n 3) 39-40. See also, G Abi-Saab, 'Fragmentation of Unification: Some Concluding Remarks' (1999) 31 NYU J Int'l L \& Pol 919, 926. 
the rest of its obligations in the wider system of international law. ${ }^{9}$ Indeed, today fears that international law is fragmenting have largely been replaced by a perception that what we are seeing can better be described as inevitable diversification of regimes, duty-bearers and institutions. ${ }^{10}$ Although welcome, this perspective introduces a raft of further important questions regarding how this diversification can be managed. ${ }^{11}$

The purpose of this article is to examine how a diversity of duty-bearers affects customary international law and its role in the unity of the system of international law. For, while it has been shown above that international treaty law has been identified as an area replete with the potential for fragmentation, it has been conversely said that customary international law is 'of primary importance to the unity of international law'. ${ }^{12}$ Due to the manner in which it is developed, there are rarely conflicts between different customary norms. ${ }^{13}$ Secondly, general (as opposed to particular) customary international law is widely accepted to be of 'general application, valid for all States'. ${ }^{14}$ In other words, all states have identical obligations under customary international law. Unlike treaty law, this gives the system of customary international law an underlying normative coherence, as it places all states on an equal normative footing. At least in part, this feature of customary international law has been identified as a key centripetal force within the system of international law. According to one interpretation, international law is a system that is designed inter alia to combat the de facto diversity of its subjects and provide a means of regulating equal states. Indeed, the 'legal fiction' that all states are 'free' and 'equal' hides the fact that states are often very different in political, geographical, ideological, religious and military terms. ${ }^{15}$ The uniform application of customary law between states is a key means of allowing 'common interests' to prevail above diversity. ${ }^{16}$ In that sense, general customary international law is an important legal glue that joins and unifies the international community of states. It creates and ensures an

9 Conclusions on Study Group on the Fragmentation of International Law, ibid, para 251. See Hassan v UK (n 7); Greenwood, ibid 42-43. See also V Todeschini, 'The Impact of International Humanitarian Law on the Principle of Systemic Integration' (2018) 23 JCSL 359.

10 Conclusions on Study Group on the Fragmentation of International Law, ibid, para 249 (on fragmentation being 'inevitable').

11 A Peters, 'Fragmentation and Constitutionalization' in A Orford and F Hoffmann (eds), The Oxford Handbook of the Theory of International Law (OUP 2016) 1029.

12 M Prost, The Concept of Unity in Public International Law (Bloomsbury 2012) 98. See also Greenwood (n 3) 40, for the differences between treaty and custom on this point. See also L Gradoni, 'The International Court of Justice and the International Customary Law Game of Cards' in Andenas and Bjorge (n 3) 369, 375.

13 Greenwood (n 3) 40.

14 Case Concerning Delimitation of the Maritime Boundary in the Gulf of Maine Area (Canada/United States of America), Judgment [1984] ICJ Rep 246, 292-93, para 90.

15 A Roberts, 'Traditional and Modern Approaches to Customary International Law: A Reconciliation' (2001) 95 AJIL 757, 768.

16 P Weil, 'Towards Relative Normativity in International Law?' (1983) 77 AJIL 413, 418. 
equality between states under customary international law that is not safeguarded by treaty law. Indeed, it has been said that 'general law' is 'possibly the most important-single vehicle of common action and understanding' between states. ${ }^{17}$

Customary international law also evidences a unity within the system of international law, in that it emerges out of the practice and opinio juris of the international community of states at a generalised level, rather than at the level of individual states. It embodies a recognition that the practice of specially affected states can be representative of all states, especially if widespread, extensive and virtually uniform. ${ }^{18}$ The idea that the practice of some states may be representative of all states is a further illustration of how customary international law functions as an important scaffold in the system of international law. It not only reinforces equality between states, but also relies upon equality between states. ${ }^{19}$ The possibility of using the notion of representation to formally correlate the duty-bearers of customary international law with the makers of customary international law is possible due to the close relationship between states and the fact that they fall within a single genus. It is likely for these reasons that despite there being enduring debates relating to the exact alchemy involved in its creation, literature on customary international law generally finds that customary international law has suffered little of the difficulties regarding fragmentation which have been experienced in treaty law. ${ }^{20}$ In particular, when binding upon states, customary international law continues to be of primary importance to what has been called the unity of international law. ${ }^{21}$ In its classical statesonly formulation, customary international law can be seen to embody what is termed in this article a unity of norms (ie all states are bound by the same norms), a unity of duty-bearers (ie norms are binding upon a single class of duty-bearers) and a unity of lawmakers (ie all norms are created by states).

While noting the important role that customary international law plays vis-àvis the unity of the system, it is immediately apparent that a diversification of duty-bearers impacts upon the unities identified above. At a baseline, the recognition that non-state actors, as well as states, are bound by customary international law interferes with the unity of duty-bearers. It also remains uncertain, within existing literature on customary law and non-state actors, whether a diversity of duty-bearers will impact on the unity of norms. In other words, it remains uncertain whether non-state actors assume the same obligations as

17 See K Keith, 'The International Court of Justice: Primus Inter Partes' (2008) 5 Int'l Org $L$ Rev 7, 21 (citing Robert Jennings).

18 North Sea Continental Shelf Cases (Federal Republic of Germany/Denmark; Federal Republic of Germany/Netherlands), Judgment [1969] ICJ Rep 3, para 73.

19 R Kolb, 'Selected Problems in the Theory of Customary International Law' [2003] Neth Int'l L Rev 119, 125.

20 The term alchemy refers to the frequent designation of opinio juris as a 'philosopher's stone' turning state practice into an obligation, see, $\mathrm{H}$ Thirlway, International Customary Law and Codification (AW Sijthoff 1972) 47.

21 Prost (n 12) 97. 
states under customary international law. Notably, it will be shown below that some authors have argued that the principle of 'unity' requires a conclusion that non-state actors bear the same norms as states under customary international law, albeit that only the relevant obligations for those actors are actively binding. There also remains a question about the role that non-state actors should play in the making of customary norms binding upon them, ie their role as lawmakers. Responding to these questions, this article evaluates how an acknowledgement that non-state actors bear obligations under customary international law affects the unity of norms and the unity of lawmakers. It brings insights to these two issues by examining them from the perspective of scholarship on armed groups and customary international law. ${ }^{22}$ Indeed, this is a key area in which scholarship on international humanitarian law is able to bring value to an issue of general importance within public international law because there has been a detailed discussion of the scope of the customary international law obligations of non-state actors (ie armed groups), with a specific focus on international humanitarian law and human rights law. ${ }^{23}$ Moreover, the discussion of these questions in associated secondary literature makes this a rich field from which more insights can be gleaned about diversity, non-state actors and customary law more generally.

\section{Armed groups and the unity of norms}

The question of how a diversity of duty-bearers impacts on the unity of norms has been the subject of recent debate in discussions about armed groups and human rights law. ${ }^{24}$ Interestingly, some authors have argued that armed groups

22 The fact that armed groups are bound by customary international humanitarian law is rarely disputed. The idea that armed groups are bound by customary international human rights law remains controversial and has been explored by, inter alia, A Clapham, Human Rights Obligations of Non-State Actors (OUP 2006); D Murray, Human Rights Obligations of Non-State Armed Groups (Bloomsbury 2016); K Fortin, The Accountability of Armed Groups under Human Rights Law (OUP 2017); J-M Henckaerts and C Wiesner, 'Human Rights Obligations of Non-State Armed Groups: A Possible Contribution from Customary International Law' in R Kolb and G Gaggioli (eds), Research Handbook on Human Rights and Humanitarian Law (Edward Elgar 2013).

23 See, inter alia, J-M Henckaerts and L Doswald-Beck, ICRC: Customary International Humanitarian Law: Volume I: Rules (CUP 2005) (hereinafter ICRC Study); S Sivakumaran, The Law of Non-International Armed Conflict (OUP 2014) 102-7; Murray (n 22) 82-8; Fortin, (n 22) 323-56. See M Wood, 'International Organizations and Customary International Law' (2015) 48 Vanderbilt J Transnat'l $L 609,619$, where he notes that there has been little discussion of the actual obligations under customary international law in the literature.

24 See, in particular, the recent conversation between Daragh Murray and Marco Sassòli on this topic on EJILTalk!. M Sassòli, 'Two Fascinating Questions: Are all Subjects of a Legal Order Bound by the Same Customary International Law and Can Armed Groups Exist in the Absence of Armed Conflict? Book Discussion', 4 November 2016 $<$ https://www.ejiltalk.org/book-discussion-daragh-murrays-human-rights-obligations-of- 
must be bound by the same spectrum of customary law norms as states - albeit that only the relevant and realistic norms for those armed groups are in effect at any time. ${ }^{25}$ To support this position, the unity of the system of international law has been identified as a major conceptual reason to maintain the view that customary international law either applies to an entity in toto or not at all. ${ }^{26}$ Additionally, recourse has been made inter alia to the famous passage in the North Sea Continental Shelf case where the International Court of Justice (ICJ) stated that general or customary rules and obligations 'by their very nature, must have equal force for all members of the international community'. ${ }^{27}$ Here, the court's reference to the term 'all members of the international community' has been interpreted to indicate that customary international law is not just 'valid for all states', but also equally valid for all entities with international personality. ${ }^{28}$ Additionally, reference has been made to Interpretation of the Agreement of 25 March 1951 between the WHO and Egypt where the ICJ stated that '[i]nternational organisations are subjects of international law and, as such, are bound by any obligations incumbent upon them under general rules of international law. ${ }^{29}$ Again, this passage has been read to support a notion that all international legal persons are bound by the entire spectrum of customary international law, including but not limited to the law of the sea, the continental shelf, space law, international humanitarian law and human rights law; albeit that the 'effect' of the obligation may only become active at such a time that the obligation becomes relevant. ${ }^{30}$

Others, including the present author, have argued that the customary character of a rule does not affect its 'personal, material, temporal or geographical scope of application'. ${ }^{31}$ Seeking to elaborate this argument further, the first part of this article demonstrates that there are good reasons to suppose that states can create a limited bundle of obligations under customary international law that are binding upon a limited class of duty-bearers. It demonstrates that this

non-state-armed-groups-3/> (last accessed 2 October 2018); D Murray, 'Author's Response: Human Rights Obligations of Non-State Armed Groups', 7 November 016 $<$ https://www.ejiltalk.org/book-discussion-human-rights-obligations-of-non-state-armedgroups-authors-response/> (last accessed 2 October 2018) where Murray states that this is an issue for further consideration. ibid.

ibid 87. North Sea Continental Shelf cases (n 18) para 63.

See ICJ (n 14) for notion that customary international law is 'valid for all states'. See Murray (n 22) 87-88 for this interpretation.

29 Murray, ibid; ICJ, Interpretation of the Agreement of 25 March 1951 between the WHO and Egypt, Advisory Opinion [1980] ICJ Rep 73, para 37.

30 Murray, ibid 87-88. The present author takes a similar view to Murray with regard to customary international law norms that are binding upon armed groups due to their control of territory, but not for armed groups which do not control territory. Fortin (n 22) 384 .

31 See Sassòli (n 24). See Fortin (n 22) 322, 384, for the position that armed groups are bound by a more limited body of customary international law in instances where they do not control territory. 
view does not interfere with the unity of customary international law, as much as it might be feared. Before expanding these points more fully, it is first pointed out that the statements of the ICJ above leave room for alternative interpretations. Significantly, in the North Sea Continental shelf case, the interests at play were purely state interests. As a result, it seems likely that the term international community' that was employed-in the statement that general or customary rules and obligations 'must have equal force for all members of the international community' - was shorthand for the phrase 'international community of states' that is often used elsewhere eg Article 53 of the Vienna Convention. ${ }^{32}$ While there is sense in arguing that the term 'international community' should be interpreted more broadly in some contexts, it is unlikely that the term can realistically include armed groups, which despite being normbearers under international law do not often share the purposes or principles of the community of states and do not constitute a group inter se. ${ }^{33}$ It can also be questioned whether in the WHO and Egypt case, the court was confirming that international organisations are bound by the full gamut of customary international law. Instead, it could have been confirming that they are simply bound by the limited number of obligations binding upon them. ${ }^{34}$ Having noted these preliminary points, it is helpful to make a further study of the concept of unity.

While it makes conceptual sense to wish to preserve the unity of customary international law, it is asserted that an argument that all entities with legal personality have equal customary international law obligations ironically risks causing more disruption to the unity of the system than a more flexible approach. Such an approach comes close to espousing a view of legal personality that conceives armed groups as equal duty-bearers to states. As such, it feeds into the fear that was so present in states during the drafting of the Geneva Conventions and Additional Protocols that the acquisition of legal personality by armed groups equates to the acquisition of Statehood. During the drafting of these treaties, states repeatedly showed themselves to be allergic to the notion that giving armed groups limited legal personality would put sovereign states and insurgents on an equal footing. ${ }^{35}$ Additionally, such a view is at odds with

32 See also, ICJ, Reparation for Injuries Suffered in the Service of the United Nations, Advisory Opinion [1949] ICJ Rep 174, 185. See also, the 1949 Draft Declaration on the Rights and Duties of States, GA Res 375 (IV) (6 December 1949), which contends that 'the States of the world form a community governed by international law'. See also, the 1970 Declaration on Principles of International Law concerning Friendly Relations and Cooperation amongt States in Accordance with the Charter of the United Nations, GA Res 2625 (XXV), asserting that all states 'are equal members of the international community'.

33 See G Abi-Saab, 'Whither the International Community?' (1998) 9 EJIL 248, who states that in order to constitute a group globally as a 'community', 'it must first attain a certain degree or threshold of intensity and stability (or normality) in relations among its members'.

34 Sassòli (n 24).

35 J Pictet, Commentary to the Geneva Convention for the Amelioration of the Condition of the Wounded and Sick in Armed Forces in the Field of August 12, 1949 (ICRC, 
the conception of legal personality put forward by the ICJ in 1949 in its Reparations Advisory Opinion. Here, the ICJ unequivocally endorsed the idea that legal personality can exist on a spectrum, stating: 'the subjects of law in any legal system' are not 'necessarily identical in their nature or in the extent of their rights'. ${ }^{36}$ In addition, it famously found that the fact that the United Nations was an 'international person' did not mean it was a 'state' or that 'its legal personality and rights and duties are the same as those of a state'. ${ }^{37}$ In doing so, the Court explicitly distanced itself from an approach to legal personality, under which only states can be subjects of international law and all duty-bearers within the international system must inevitably have the same obligations. ${ }^{38}$

Additionally, it is important to note that the unity which has been called upon to justify an argument that all entities with legal personality must be bound by all norms of customary international law, is less strict than it may appear. For while customary international law plays an important adhesive role within the system of international law, several aspects of that unity have become graduated in recent years. For example, while it was once possible to say that all states are bound by the same general norms of customary international law and that all customary norms have the same character as each other, this is no longer entirely the case. Indeed, already several decades ago, it was noted that a "normativity' has developed within customary international law, in that not all customary norms are equal, in terms of hierarchy or gravity eg jus cogens norms. ${ }^{39}$ This development was seen then and-can be seen now-as part of a greater trend within international law to replace 'the monolithically conceived normativity of the past by graduated normativity'. ${ }^{40}$ In a similar vein, it has been commented that there are differences in the methodology employed in different areas of customary international law. In some areas of international law, there has been a trend to place a greater emphasis upon opinio juris, rather than state practice. For instance in areas where the norm under scrutiny is humanitarian in character, judicial institutions have on occasion shown themselves willing to give more emphasis to opinio juris over state practice. ${ }^{41}$ There is also a willingness in

Geneva 1952) 60 (hereinafter Pictet, Commentary to Geneva Convention I), 60. See also, statements by the delegations from the DRC and Iraq. Official Records of the Diplomatic Conference on the Reaffirmation and Development of International Humanitarian Law Applicable in Armed Conflicts, Geneva, 1974-1977, vol VII, CDDH/SR.50, 104 and vol VIII, CDDH/I/SR.32, 335 [64].

36 Reparations (n 32) 178.

37 ibid 179.

38 R Portmann, Legal Personality in International Law (CUP 2010) 43.

39 Weil (n 16).

40 ibid 421.

41 See eg ICTY, Prosecutor v Kupreskić et al (Judgment), Case No IT-95-16-T, 14 January 2000, para 527. See also, Appeal Judgment of the Extraordinary Chambers in the Courts of Cambodia, Case No 001/18-07-2007-ECCC/SC, 3 February 2012. See also ILC, Second Report on Identification of Customary International Law, 22 May 2014, A/CN.4/672, para 28 (hereinafter ILC Second Report on CIL) rejecting an approach where opinio juris is decisive, but confirming that 'there may, nonetheless, 
some areas to recognise state action which in other circumstances could be conceived to be the seed of a new norm of customary international law, as a violation of an existing norm of customary international law. ${ }^{42}$ This development is a further indication that the unity of the system is perhaps less all-encompassing than it may sometimes be suggested.

The idea that customary international law is a unitary system which is binding equally upon all entities with legal personality-rather than only upon all states - is also hard to tally with the fact that there is plentiful evidence that different entities are bound by different customary international law obligations. For example, it has long been recognised that individuals are subjects of international law, capable of bearing rights and duties not only under treaty law, but also under customary international law. After the Second World War, individuals were largely prosecuted for war crimes under the customary international law version of international humanitarian law provisions, so that prosecutors could get around the general participation clause in Article 2 of the Hague Convention $1907 .{ }^{43}$ Likewise, many of the prosecutions of individuals carried out by the two ad hoc tribunals - particularly those by the ICTY - have been based on violations of customary international law. ${ }^{44}$ While it may be pointed out that both states and individuals are bound by many of the provisions underlying these crimes, it is significant that the nature of these norms is clearly different for different duty-bearers. For instance the breach of the obligations binding upon individuals in common Article 3 leads to individual criminal responsibility while the breach of the same obligation binding upon states leads only to civil-type responsibility. ${ }^{45}$ In other words, these norms provide another example that the system of customary international law contains gradations between and within norms that reflect inter alia the diversity of duty-bearers within it.

In a similar vein, the distinction between international and non-international armed conflicts can be held up as evidence of the fact that states and armed groups are not bound by the same norms under customary international law. This emerges out of the fact that there are different legal regimes for international armed conflicts (ie conflicts between states) and non-international armed conflicts (ie conflicts between states and one or more armed groups). For despite armed groups having legal personality under international humanitarian law,

be a difference in application of the two-element approach in different fields (or, perhaps more precisely, with respect to different types of rules)'.

42 Roberts (n 15) 776.

43 For a discussion of this approach, see Digest of Laws and Cases, Law Reports of Trials of War Criminals, Selected and Prepared by the United Nations War Crimes Commission (London 1949) vol XV, 12-13.

44 See B Schlủ tter, Developments in Customary International Law (Martinus Nijhoff 2010) 177-86 on the different approaches of the ad hoc tribunals to custom.

45 For discussion of this rule, see ICRC Study (n 23) 530-32. See Prosecutor v Tadic, Case No IT-94-1, Decision on the Defence Motion for Interlocutory Appeal on Jurisdiction, 2 October 1995, para 129 (Tadić Jurisdiction Decision). 
they will never be held bound by the customary provisions of international humanitarian law that apply in international armed conflicts (unless they are acting under the overall control of a third state). ${ }^{46}$ Likewise, even within the non-international armed conflict framework, there are a few norms of customary international law, which are held to be binding upon states but not armed groups, indicating that different duty-bearers may bear different obligations (or levels of obligation) within the same framework. A pertinent example is Article 1 of the Geneva Conventions under which the High Contracting Parties undertake to respect and to ensure respect for the present Convention in all circumstances. ${ }^{47}$ In its study on customary international law, the ICRC has indicated that although Article 1 of the Geneva Conventions applies as a matter of custom in non-international armed conflicts, it is binding only upon states. ${ }^{48}$ Likewise, in non-international armed conflicts, only states-and not armed groups - have been held to be under the customary obligation to investigate and if appropriate prosecute war crimes committed by their nationals or armed forces or those that have been committed on their territory or under their jurisdiction. ${ }^{49}$ These rules provide a further demonstration that the system of customary international law is able to respond to the diversity of duty-bearers within it.

Outside the international humanitarian law framework, there are further examples indicating that non-state actors are bound by different norms of customary international law to states. A key example is the fact that while states are bound by Article 2(4) of the UN Charter in its customary form, it is generally considered that non-state actors such as individuals and armed groups are not. ${ }^{50}$

46 In this situation, the armed conflict will effectively be between two states and therefore international in character. See inter alia S Sivakumaran, The Law of NonInternational Armed Conflict (OUP 2012) 225-28.

47 On the extent to which this provision contains obligations erga omnes (partes), see $\mathrm{M}$ Longobardo, 'The Contribution of International Humanitarian Law to the Development of the Law of International Responsibility Regarding Obligations Erga Omnes and Erga Omnes Partes' (2018) 23(3) JCSL 392-93. On the analysis of the due diligence requirements implied in Common art 1, see A Berkes, 'The Standard of Due Diligence as a Result of Interchange between the Law of Armed Conflict and General International Law' (2018) 23(3) JCSL 441-43.

48 ICRC Study (n 23) 495-96. The requirement that armed groups respect international humanitarian law is set forth in inter alia common art 3 of the Geneva Conventions. ibid 607-11.

50 See ICJ, Accordance with International Law of the Unilateral Declaration of Independence in respect of Kosovo, Advisory Opinion [2010] ICJ Rep 403, para 80, where discussing art 2(4) of the United Nations Charter, the Court stated that 'the scope of the principle of territorial integrity is confined to the sphere of relations between States'. See also the Nicaragua case para 188 where the ICJ indicated that the customary international law version of art 2(4) is similar to the treaty provision. For discussion of this view, see C Kreß, 'The International Court of Justice and the "Principle of Non-Use of Force" in M Weller (ed), The Oxford Handbook of the Use of Force in International Law (OUP 2015) 572. 
This is a good example to challenge the argument that entities with legal personality are inevitably bound by all norms of customary international law, but only those that are viable and/or relevant are 'in effect'. ${ }^{51}$ For, as a matter of capacity, armed groups could very well adhere to the prohibition of the use of force which is surely relevant to many of them; yet, doctrine and case law indicate that they are simply not bound by this norm. Taken together, the examples above demonstrate that while concluding that a norm is customary in character, there is no strict conceptual need to conclude that it is therefore binding upon all non-state actors, as well as states. Equally, when recognising that an entity has legal personality, there is no strict conceptual need to argue that it is therefore bound by the full spectrum of customary international law. It is noteworthy that the second report of the ILC study on customary international law states: 'It is not of course the object of the present topic to determine the substance of the rules of customary international law, or to address the important question of who is bound by particular rules (states, international organisations, other subjects of international law) ${ }^{52}$ In doing so, the report confirms a view that it is not self-evident that states, international organisations or other entities with legal personality, such as armed groups, are all bound by the same norms of customary international law. Indeed, Sir Michael Wood-the Special Rapporteur on the ILC's study and drafter of the cited report - has confirmed elsewhere a view that there is no reason to assume that international organisations have the same obligations as states, just because they have international legal personality. ${ }^{53}$

It has long been accepted within the field of customary international law that there is scope for differentiation between duty-bearers and norms, in the area of what is called 'regional', 'special' or 'particular' custom. The ICJ has noted on many instances that there may be some rules of customary international law, which are only binding upon some states. ${ }^{54}$ Usually, particular custom emerges in a particular and restricted geographical area and relates to regional-specific customs that have emerged out of the particular political, territorial, geographical or historical circumstances of the states in question. ${ }^{55}$ Particular customary rules may involve a group of states but may also emerge out of the practice and opinio juris of two states. The existence of particular custom confirms that it would be overly cautious to conclude that the principle of unity in the framework of customary international law prevents all or some states creating

51 Murray (n 22) 88 and see n 30.

52 ILC Second Report on CIL (n 41) para 13.

53 Wood (n 23) 619.

54 See inter alia Asylum Case (Colombia/Peru), Judgment [1950] ICJ Rep 266, 276; Case Concerning Rights of Nationals of the United States of America in Morocco (France $v$ United States of America), Judgment [1952] ICJ Rep 176, 200; Case concerning Right of Passage over Indian Territory (Portugal v India), Judgment (Merits) [1960] ICJ Rep 6, 39; Military and Paramilitary Activities in and against Nicaragua (n 50) 105, para 199.

55 ILC, Third Report on Identification of Customary International Law, 27 March 2015, A/CN.4/682, para 82 . 
customary obligations which are limited to certain duty-bearers. While there is no doubt that customary international law plays an important role in preserving the coherence of the system of international law, the paragraphs above have demonstrated that a recognition that non-state actors can be duty-bearers of different norms to states under customary international law does not pose problems to the unity of international law. The first and the most important reason for this is that it leaves intact the unity of the system as it applies between states. The fact that different subjects of international law may have different obligations under international law need not affect the fact that states have the same general obligations to each other under general customary international law. Secondly, it has been shown that the system of customary international law already holds considerable existing scope for diversity between duty-bearers and between norms.

\section{Armed groups and the unity of lawmakers}

The next part of this article examines whether in addition to consulting the opinio juris and practice of states, the practice of armed groups and their opinio juris also needs to be consulted when determining the content of norms binding upon them. This question, which has been raised across the board on literature relating to non-state actors, is another key area relating to the so-called unity of customary international law on which a lack of clarity remains, not only among scholars, but also between different institutions. ${ }^{56}$ In literature addressing armed groups, scholars disagree as to whether armed groups can be bound by customary international law if their practice is not consulted in its formation. ${ }^{57}$ During the process of determining the rules of customary international humanitarian law binding upon states and armed groups in non-international armed conflicts, ICRC drafters decided not to take into account the 'practice of armed opposition groups' as it 'does not constitute State practice as such'. ${ }^{58}$ They said that while such practice may contain 'evidence of the acceptance of certain rules in non-international armed conflicts', its 'legal significance' is 'unclear'. ${ }^{59}$ As a result, in assessing whether a

56 For literature in other fields looking at this question, see inter alia I Gunning, 'Modernizing Customary International Rights Law: The Challenge of Human Rights' (1990-1991) 31 Va J Intl L 211, 221; Wood (n 23); J Charney, 'Universal International Law' (1993) 87 AJIL 529, 536.

For discussion of this, see A Roberts and S Sivakumaran, 'Lawmaking by Nonstate Actors: Engaging Armed Groups in the Creation of International Humanitarian Law' (2012) 37 Yale J Int'l L 107, 122-23. See also, M Sassòli, 'Taking Armed Groups Seriously: Ways to Improve their Compliance with International Humanitarian Law' (2010) 1 JIHLS 5, 21; Kolb (n 19) 129 and A Bellal and Ezequiel Heffes, 'Yes, I Do': Binding Armed Non-State Actors to IHL and Human Rights Norms through Their Consent' (2018) 12 Human Rights \& International Legal Discourse, 120. ICRC Study (n 23) xlii.

59 ibid. 
particular rule of humanitarian law was binding upon armed groups and states in non-international armed conflict, the ICRC adopted the same methodology as when assessing whether a norm was binding only upon states in international armed conflict, assessing: (i) state practice and (ii) opinio juris. In taking this position, the ICRC (probably wisely) refrained from actively engaging in the legal debate about the formation of customary rules binding upon non-state actors. Instead, it concluded that the existence of doubt on the matter was a reason enough to exclude the practice of armed groups from the study.

Unlike the ICRC, the Appeals Chamber of the International Criminal Tribunal for the former Yugoslavia (ICTY) took note of the practice of armed groups when determining the content of the legal framework that was binding in non-international armed conflicts. Specifically, it took note of the instructions issued by Mao Tse-Tung to the Chinese 'People's Liberation Army' in his manifesto and the rules of discipline. ${ }^{60}$ It also took note of a declaration by the Farabundo Marti National Liberation Front (FLMN) in its conflict against El-Salvador. Here, the FLMN declared that it was willing to comply with the provisions of common Article 3 and Additional Protocol II. ${ }^{61}$ In explaining its choice to refer to this practice by armed groups, the ICTY Appeals Chamber stated that it viewed 'the behaviour of belligerent states, governments and insurgents (emphasis added)' to be 'instrumental in bringing about the customary international law rules at issue. ${ }^{62}$ The fact that the ICTY Appeals Chamber approached this legal question differently to the ICRC highlights the methodological dilemma facing practitioners in this area. With some estimates suggesting that at times, there have been over 1000 armed groups in operation in Syria alone, it is clear that it would never be possible to make a systemic review of the practice of all armed groups in the world. ${ }^{63}$ But thanks to the work of the pioneering non-governmental organisation Geneva Call, a review of the practice and opinio juris of some armed groups would now be at least possible. Geneva Call collects and stores a wealth of information about which legal norms armed groups consider to be binding upon them through international codes of conduct, deeds of commitment, constitutions and correspondence. ${ }^{64}$ The fact that such a review is now logistically possible increases the importance of determining whether such a review is constitutively necessary and how it would be carried out as a matter of methodology.

While the examination of the theme of unity above has shown that it is possible to inject diversity into customary international law at the level of

60 Tadić Jurisdiction Decision (n 45) para 102.

61 ibid 106.

62 ibid 108.

63 See eg BBC, 'Guide to the Syrian Rebels' BBC (13 December 2013) <http://www.bbc. com/news/world-middle-east-24403003> (last accessed 2 October 2018)

64 See, Geneva Call's 'Their Words: Directory of Armed Non-State Actor Humanitarian Commitments' <http://theirwords.org/pages/geneva-call $>$ (last accessed 2 October 2018). 
duty-bearers, it also serves to highlight some of the difficulties in accommodating non-state actors at the level of lawmakers. ${ }^{65}$ In the first instance, it demonstrates the importance of questioning whether armed groups can be said to represent a single generic legal category inter se, in the same way as states. Indeed, it was commented above that states share a sense of community through their formal adherence to common principles. It was also commented that although states have varied outward characteristics (size, geographical position) and inward ideologies (politics, ideological bent), they largely have the same legal capacities and functions. States all exercise control over territory, have a fixed population, government and capacity to enter into relations with other states. Moreover, as mentioned above, despite their de facto heterogeneity, states are considered equal from a legal perspective. ${ }^{66}$ It has been asserted above that it is largely these principles of equality and community that make it conceptually possible to argue that the practice of several states is representative of the rest, in the manner envisaged by the 'specially affected' test set out in the North Sea Continental Shelf case. ${ }^{67}$ The test relies upon the ability of specially affected states to represent the community of states in their practice. The same goes for the rule which requires state practice to have been both extensive and virtually uniform for the emergence of a generally binding rule. ${ }^{68}$ While it is practically possible to imagine that some armed groups may be specially affected by a particular issue, it is less likely that several armed groups could ever be considered representative of armed groups per se.

The reason for this is that armed groups less obviously embody the principles of community that the first part of this article have shown are so central to customary international law. ${ }^{69}$ Notably, the variation between armed groups can be profound on issues as fundamental as territorial control, longevity, relationship with the civilian population and governance activities. Armed groups also have varying capacities and as a result differ inter se in their ability to fulfil obligations under international law. For example, some armed groups are bound by and are able to comply with norms found in common Article 3, and others are bound by and are able to comply with the more extensive norms found in Additional Protocol II. ${ }^{70}$ It is also significant that there is no international organisation equivalent to the United Nations, which binds armed groups

See, S Sivakumaran, 'Beyond States and Non-State Actors: The Role of StateEmpowered Entities in the Making and Shaping of International Law' (2017) 55 Columbia J Transnl L 343 for a recent contribution to the debate distinguishing between (i) states (ii) non-state actors and (iii) State-empowered entities in the making and shaping of international law. See also Wood (n 23), for a discussion of international organisations made up of states.

66 See eg art 2(1) of the UN Charter which confirms that the United Nations is based on the 'sovereign equality' of all members. See Roberts (n 15) 768.

67 North Sea Continental Shelf cases (n 18) para 74.

68 ibid.

69 See also Kolb (n 19) 125, who remarks: 'sovereign equality is .... the very starting point which accounts for the possibility of state practice and custom created by states'. 
together, with common purposes and principles. Armed groups rarely have relationships with each other of the sort that form the conceptual basis of customary international law rules. Generally, armed groups only have relations with the state(s) or armed group(s) against which they are fighting, and these are often antagonistic. This provides further evidence of the point made above that it is hard to envisage a situation where it could be comfortably said that the practice or views of several armed groups could be said to be representative of all armed groups. In addition, although some armed groups (and even armed groups and states) may sometimes have common concerns or political philosophies, there is a general lack of collective understanding between armed groups, and these are the core principles upon which the customary process are recognised to be based. ${ }^{71}$

There are also problems with the fact that armed groups are transitory in character. Although nowadays armed conflicts are often protracted, the lifespan of armed groups still cannot be compared to that of states, which are assumed to have a longer existence. As a result of states' presumed longevity, their contribution to the development of customary norms is symbolically assumed to count into the future, securing the legitimacy of the created norms into the future as well. In contrast, armed groups are only tolerated legally, in the sense that they are recognised to be the bearers of a restricted number of legal obligations for a limited period of time, due to specific factual circumstances (ie the existence of an armed conflict) rather than the nature of their identity per se. This raises the important practical observation that an acceptance that armed groups can contribute to the creation of international norms binding upon them would not necessarily solve the problem of ownership of norms that is sometimes raised as a reason for their practice to be included in law-making processes. ${ }^{72}$ There can be no assumption that the armed groups active today will still exist in 10 years. As a result, even if today's armed groups are involved in norm creation, there is no guarantee that the armed groups of the future will feel any affinity for those norms. ${ }^{73}$ Moreover, and perhaps most importantly, presumably the principle of equality in international humanitarian law would demand that if the practice of armed groups is to be taken into account in the determination of the customary international humanitarian law binding upon them, it would have to be taken into account alongside the practice of states. This raises another serious

71 See Sassòli (n 57) 23-24 for the notion that armed groups may have common concerns. M Byers, Custom, Power and the Power of Rules (CUP 1999) 148.

72 Sassòli (n 57) 29. For a development of the concept of 'ownership of norms', see also, A Bellal and S Casey-Maslen, 'Enhancing Compliance with International Law by Armed Non-State Actors' (2011) 3 Goettingen J Int'l L 175, 191 and Sivakumaran (n 23 ) 140. See also, S Rondeau, 'Participation of Armed Groups in the Development of the Law Applicable to Armed Conflicts' (2011) 93 International Review of the Red Cross 649, 654.

73 See Bellal and Casey (n 72) 191 where they point out that relatively few armed nonstate actors have used this argument to oppose the general application of international humanitarian norms. For examples, where this has been the case, see Roberts and Sivakumaran (n 57) 127. 
difficulty. For, it is unclear how weight would or could be allocated to the (potentially conflicting) practice and opinio juris of two different generic entities when seeking to determine the obligations between them. ${ }^{74}$ In a similar vein, it is unclear how the notion of representativeness can translate across two different kinds of entities.

It may be partly due to these myriad unresolved conceptual problems that the ICRC decided not to take the practice of armed groups into account in its 2005 study of customary international law and subsequent updates. Yet, arguably the ICRC's solution of relying on only state practice and opinio juris as evidence of obligations binding upon states and armed groups is also methodologically problematic, in particular, with respect to some norms. At first glance, concerns may be raised that it sits uneasily with traditional conceptions of custom that sees it as law emerging directly out of an 'interaction' between eventual duty-bearers. ${ }^{75}$ Yet on examination, it is argued that it is not the fact that armed groups have not taken part in the creation of obligations binding upon them that is in fact most problematic. In modern custom, an identical correlation between duty-bearers and makers is rarely achieved. With nearly 200 states now in existence, it has long been accepted that customary law binds states which have not contributed to its formation or deliberately acquiesced to it. ${ }^{76}$ What is more problematic is the notion that an assessment of state practice and opinio juris can result in obligations binding upon another type of entity ie armed groups. For such an approach ignores the crucial role that the identity of the actor often plays in the emergence of practice and opinio juris. ${ }^{77}$ With respect to many issues, it is predominately the fact that a state is a state that determines (i) how it acts and (ii) what it believes are its legal obligations. While this may not be true for many norms of humanitarian law applying in non-international armed conflicts, for which the underlying practice and opinio juris is driven largely by the identity of their beneficiaries (ie civilians) and wider considerations of humanity, it is certainly true of much of human rights law where the obligations that states owe to individuals emerge out of the special capacities, responsibilities and powers of states vis-a-vis individuals. For example, if states make it their practice to grant habeas corpus rights to detainees and believe that they are obliged to do so, their actions and beliefs regarding their legal obligations stem from the fact that they are states. ${ }^{78}$ This is also true of many international humanitarian law rules

74

75

76

See inter alia Charney (n 56) 536-37, H Charlesworth, 'Customary International Law and the Nicaragua Case' (1984-1987) 11 Aust YBIL 1, 3. See also, ILA Final Report of the Committee on Formation of Customary (General) (2000) International Law 24.

77 Perhaps, this is what Sassòli meant when he said 'the question still remains open why non-state actors should be bound by the same rules as States?' Sassòli (n 57) 13.

78 It may be for similar reasons that Jean d' Aspremont concludes that the practice of non-state actors can only be germane to the emergence of customary rules whose object is to regulate non-state actors. Jean d' Aspremont, 'Conclusion: Inclusive LawMaking and Law Enforcement Processes for an Exclusive Legal System' in J 
applying in international armed conflicts eg the obligations in an international armed conflict for states to grant prisoner of war status to combatants. ${ }^{79}$ It is also a characteristic of some norms in non-international armed conflict where the nature of the obligation is specifically linked to the identity of the duty bearer, as a state eg the states' obligation to investigate and if appropriate prosecute war crimes committed by their nationals or armed forces or those that have been committed on their territory or under their jurisdiction. ${ }^{80}$

With regard to international humanitarian law, little attention was given to this issue in the ICRC's study on international humanitarian law. Instead, the ICRC simply drew upon state practice and opinio juris when seeking to identify which norms were binding upon states and armed groups. It is asserted that this methodology was largely unproblematic when it comes to international humanitarian law. For it has been noted above that in many instances, practice and opinio juris relating to international humanitarian law norms is often not identity-specific. In addition, it is significant that the ICRC did implicitly pay attention to these issues in its assessment of international humanitarian law applying in non-international armed conflicts, by virtue of the principle of equality. When states include a particular rule in their military manuals that are applicable in or have been applied in non-international armed conflicts, the principle of equality often allows a deduction that the states believe the rule to be equally binding upon armed groups. ${ }^{81}$ Significantly, the notion that armed groups can be bound by customary international law when its constitutive components evidence a state intention for them to be bound holds similarities with the argument that armed groups can be bound by treaty law, by means of state consent. ${ }^{82}$ Successive authors have considered this theory-sometimes called the legislative jurisdiction theory - to be the most persuasive to explain how armed groups are bound by common Article 3 and Additional Protocol II. ${ }^{83}$ According to this theory, states can bind individuals and armed groups in their jurisdiction by means of treaty law, on the basis of their intention for armed groups to be bound. In essence, this theory relies upon precedent reflected in inter alia the Courts of Danzig case that in some circumstances states can confer rights or obligations upon non-state actors without securing their consent. $^{84}$ It

d'Aspremont (ed), Participants in the International Legal System: Multiple Perspectives on Non-State Actors in International Law (Routledge 2011) 430.

ibid 607-11. Indeed, there may be a correlation between identity-specific norms and those which have been found to be only binding upon states in non-international armed conflict.

81 It has been shown above already that this is not the case for all norms, but it is true for most substantive rules.

82 Murray, 'Author's Response' (n 24) who also makes this connection.

83 Fortin (n 22) 206-07; Murray (n 22) 117; Sivakumaran (n 23) 2402.

84 PCIJ, Jurisdiction of the Courts of Danzig, Advisory Opinion, 3 March 1928, Series B, No $15,18-21$. 
demonstrates that the pacta tertiis rule does not apply in the same way to nonstate actors, as it does to states and finds that states can bind third parties to treaty law, by virtue of being the main architects of the legal order. ${ }^{85}$ There is no reason why there should not be scope for a similar dynamic to be at play within the customary international law framework.

Yet, in other fields of law - for instance human rights law-state practice and opinio juris are more closely tied to the identity of the actor as a state. It is this observation that makes it more difficult for the ICRC to draw upon human rights law to 'support, strengthen and clarify analogous principles of international humanitarian law' that apply in non-international armed conflict, without giving attention to how these state-specific provisions can be the source of obligations binding not only upon states but also upon armed groups. ${ }^{86}$ For example, when setting out the prohibition of arbitrary deprivation of liberty, the ICRC Study relies heavily on human rights law treaty provisions and pronouncements from human rights treaty bodies as evidence of state practice and/or opinio juris, but it does not consider how state-specific practice or opinio juris can create human rights obligations for non-state actors. ${ }^{87}$ This could perhaps have been achieved by indicating a view in the Study's introduction that human rights obligations are binding upon armed groups. It could have also been arguably achieved by identifying state practice and opinio juris that demonstrate a belief on the part of states that armed groups are bound by particular human rights norms. Physical practice might include the deployment of national experts or experts from state-empowered entities to assist an armed group adhere to human rights norms or the provision of training to armed groups on the content of human rights. ${ }^{88}$ It might also include the provision of logistical assistance, funding or seconded staff members by states or states-empowered entities for

85 This is contrary to the position set out in A Cassese, 'The Status of Rebels under the 1977 Geneva Protocol on Non-International Armed Conflicts' (1981) 30 ICLQ 416, 423. Interestingly, Christine Chinkin argues that the humanitarian goals of international humanitarian treaty law may be the driving force behind their ability to constitute an exception to the pacta tertiis rule. See C Chinkin, Third Parties in International Law (OUP 1993) 133.

86 ICRC Study (n 23) xxxi. See also Sassòli (n 57) 17 'When the ICRC claims in its Customary Law Study that 136 (and arguably even 141) out of 161 rules of customary humanitarian law .... apply equally to non-international armed conflicts, did it bear in mind that for each of these rules such applicability necessarily implies that they are also binding upon armed groups?'. See Fortin (n 22) 331.

87 See ICRC Study (n 23) 347-52 on arbitrary detention where there is heavy reliance on human rights treaties for norms applying in non-international armed conflicts.

88 For the relevance of state-empowered entities for the making of customary international law, see Sivakumaran (n 65). See eg the training given by Opération Des Nations Unies en Cote d'Ivoire (ONUCI) to members of Forces Nouvelles in April 2009 on issues such as arbitrary detention, preventative detention and the use of force. https://onuci.unmissions.org/droits-de-1\%E2\% 80\%99homme-1\%E2\%80\%99onuciforme-des-officiers-des-forces-nouvelles (last accessed 2 October 2018). 
setting up of a United Nations field office with a mission to monitor the conduct of armed groups under human rights law. ${ }^{89}$ Acts that may consist of both verbal practice and/or a legal conviction that armed groups are bound by human rights law may include states voting on resolutions emanating from either the UN Human Rights Council, the UN General Assembly or UN Security Council holding armed groups to account under human rights law ${ }^{90}$; the signing or witnessing of peace agreements containing human rights norms binding upon armed groups ${ }^{91}$; policy statements or press releases emanating from states holding armed groups to account under human rights norms ${ }^{92}$; records of correspondence between states and armed groups reminding them of their obligations under human rights norms or seeking their compliance with those norms ${ }^{93}$; special agreements between states and armed groups on human rights norms ${ }^{94}$; a widely ratified treaty seeking to impose human rights obligations upon armed groups ${ }^{95}$; statements by state-empowered entities (eg Commissions of Inquiry, Special Rapporteurs, treaty bodies) indicating that armed groups are bound by human rights norms. ${ }^{96}$ Although this kind of practice was only sometimes referred to by the ICRC, it has been subject to a more

89 Many United Nations field offices monitor the adherence of armed groups with human rights law. See eg the review of Taliban practice against human rights norms by the United Nations Assistance Mission in Afghanistan in its annual and mid-year Protection of Civilians in Armed Conflict reports.

90 There have been several far-reaching studies documenting and studying the language adopted by states with respect to armed groups and human rights law before the Human Rights Council and the United Nations General Assembly and Security Council. See eg Geneva Academy of International Humanitarian Law and Human Rights, Academy In-Brief No 7: Human Rights Obligations of Armed Non-State Actors: An Exploration of the Practice of the UN Human Rights Council, 2016. See also, G Fox, K Boon and I Jenkins, 'The Contributions of the United Nations Security Council Resolutions to the Law of Non-International Armed Conflict: New Evidence of Customary International Law' [2018] Am UL Rev 649.

91 See eg the Comprehensive Peace Accord signed between the Nepal Government and the Communist Party of Nepal (Maoist), 22 November 2006 under which 'both sides reconfirm their commitment to the respect and commitment to human rights'. Similarly, see the Peace Agreement between the Government of Sierra Leone and the Revolutionary United Front, 30 November 1996.

92 Recourse may be had to inter alia reports by governments on human rights situations around the world, such as the US State Department's annual Country Reports on Human Rights Practices.

93 Interestingly, correspondence of this kind exists relating to the Spanish Civil War and similar diplomatic records exist from the American Civil War. See Fortin (n 22) 96, 103, 105-07.

94 Common art 3 of the Geneva Conventions encourages parties to an armed conflict to enter into special agreements with eachother on humanitarian issues. Sivakumaran (n 23) 128-32 for a review of agreements between armed groups and states containing human rights commitments.

95 See eg the African Union Convention for the Protection and Assistance of Internally Displaced Persons in Africa, although note that its binding forces on armed groups as opposed to their members is contentious. See Fortin (n 22) 232-38. 
systematic review by other authors, when making an assessment of whether armed groups are bound by customary international human rights law. ${ }^{97}$

Before concluding, it remains to add that although this article has found that it is hard to envisage how the practice and views of armed groups can play a formal role in the making of customary international law, it finds undeniable force in the argument that armed groups should contribute to shaping of norms binding upon them. ${ }^{98}$ Sivakumaran and Roberts have pointed out the possibility of steering an 'intermediate course' between those who argue that armed groups should have no role in the law-making process and those who argue that armed groups will only be bound by norms, if they played a role in their creation. Like Sassòli and later Rondeau, they point out that there is precedent for armed groups playing a role in the drafting of new treaty regimes. ${ }^{99}$ For example, it was in recognition of the importance of 'broad participation' that representatives of 11 national liberation movements participated as observers in the drafting of the Additional Protocols in $1974-77 .{ }^{100}$ In reality, the participation of these groups was controversial and their interventions were often unhelpful, amounting to allegations regarding the states against which they were fighting. ${ }^{101}$ Yet, these problems aside, it cannot be denied that a consideration of armed groups' practice and views is necessary in law-making processes, not in a formal sense, but to prevent the legal framework from becoming overly biased towards the needs and aspirations of states. ${ }^{102}$ As Sassòli has pertinently pointed out, if the views of only one party are taken into account in the making of international humanitarian law, it will inevitably become 'less realistic and effective' ${ }^{103}$ Significantly - across the board in literature on non-state actors - it is noted that if the views of actors are excluded from law making entirely, there is a high risk of their non-compliance. ${ }^{104}$ This underlines the important and oft-stated value in encouraging armed groups to take ownership of humanitarian

96 For a non-exhaustive but far-reaching review of recent practice, see Fortin (n 22) 1821. For an earlier review, see L Zegveld, The Accountability of Armed Opposition Groups in International Law (CUP 2002) 45-51.

97 A Constantinides, 'Human Rights Obligations and Accountability of Armed Opposition Groups: The Practice of the UN Security Council' (2010) 4 JHRILD 89, 102-3. See also Zegveld ibid who assesses whether the practice of international bodies regarding armed groups and human rights law is 'general'.

98 See, Sivakumaran (n 65) for the distinction between 'law-making' and 'law-shaping'.

99 Roberts and Sivakumaran (n 57) 120.

100 Sassòli (n 57) 22. See Final Act of the Diplomatic Conference on the Reaffirmation and Development of International Humanitarian Law Applicable in Armed Conflicts, Official Records (n 35) vol I, 7.

101 Records from the diplomatic conference show that it was challenging for the Conference to agree which non-state groups should be invited. See Official Records (n 35) vol V, CDDH /SR.2-16. For examples of politically charged interventions, see those of FRELIMO, ZAPU, SWAPO, PLO, ANC, ZANU Official Records (n 35) vol V, CDDH/SR.19, paras 34-6, 50-3, 55, 60, 70, 77.

102 Sassòli (n 57) 22.

103 ibid. See also Rondeau (n 72) 654.

104 Charney (n 56) 533. 
norms, by signing unilateral declarations, special agreements or hybrid treaties. ${ }^{105}$ It also underlines the importance of finding ways for the "excluded voices' of armed groups to be heard in state-dominated fora where their interests may otherwise be ignored. ${ }^{106}$ While it may not be constructive or politically possible for armed groups to take part in future formal lawmaking sessions, there is certainly scope for their views to be communicated through other channels, eg through an NGO intermediary. ${ }^{107}$

\section{Conclusions}

This article has brought insights into the question of how and whether customary international law can accommodate diversity, while safeguarding the most important aspects of the unity for which it is often known. It has shown that despite the important role that customary international law plays in the structure of international law, it can accommodate considerable diversity at the level of duty-bearers. By demonstrating precedent for non-state actors to bear different obligations under customary international law to states, the article shows that the recognition that non-state actors can have obligations under customary international law need not impact upon the role of customary international law as an important adhesive between states. This is largely because the fact that different subjects of international law may have different obligations under international law need not affect the fact that states have the same general obligations to each other under general customary international law. In contrast, the article finds that it is harder for customary international law to accommodate diversity at the level of its makers. Most importantly, it shows that it is conceptually difficult to imagine how the practice of armed groups could be taken into account alongside the practice of states, in the making of customary international law binding upon armed groups and states. It points out that the greatest obstacle is to figure out how the notion of representativeness translates across entities of different kinds. Yet, while rejecting this approach, the article also points out that there are difficulties in an approach finding that state practice and opinio juris of states produce obligations binding upon another type of actor ie armed groups. In doing so, the article points out that the identity of the actor (or its genus) is often key to defining its practice and beliefs. This factor makes it difficult to argue that any obligations that emerge out of that practice and belief can be transposed onto different kinds of actors. Asserting that this is particularly a problem with human rights law, the article ends by making suggestions about how this methodology can be adjusted to make it more legitimate.

105 See inter alia Roberts and Sivakumaran (n 57), Sassòli (n 57), Bellal and Casey (n 72), B Saul, 'Enhancing Civilian Protection by Engaging Non-State Armed Groups under International Humanitarian Law' (2016) 22 JCSL, 39.

106 Roberts and Sivakumaran (n 57) 123-24.

107 See Gunning (n 56) on the role of non-governmental organisations on the making of international law. 
In putting forward these views, the article ends by focusing on the paradox that by insisting that states are the main architects of international law-while simultaneously finding it to be incapable of accommodating diversity at the level of lawmakers - we are creating problems of legitimacy and authority. In reflecting on this final point in these conclusions, one cannot help but be reminded of Rosalyn Higgins famous caution of our tendency to erect an 'intellectual prison of our own choosing and then declar[e] it to be an unalterable construct'. ${ }^{108}$ One is led to wonder if it is not the height of obstinacy to refuse to change the way an existing system works, in the knowledge that we risk its effectiveness. Yet, on the other hand, the article has shown that the position of states as the prime makers of customary international law is a central cohesive force within the system of international law. Even more significantly, it has shown that there are significant conceptual problems with understanding how the practice of armed groups could be successfully integrated into an assessment of customary international law alongside that of states, while respecting the principles of representativeness upon which customary international law has been based. Until it is satisfactorily shown how these problems can be resolved, the article finds it sensible to hold off altering the existing system. In doing so, the article underlines the value of expending energy on pursuing alternative avenues to accommodate diversity at the level of lawmaking. As these processes and mechanisms gain more legitimacy and their effectiveness becomes evident, it is possible that they will be increasingly viewed not as being outside the system, but instead as part of a more comprehensive and heterogeneous system, which has a variety of tools to accommodate and address a diversity of actors within it.

108 R Higgins, Problems and Process, International Law and How We Use It (Clarendon 1994) 49. 